\title{
TRANSLATOR'S ROLE AND CONTRIBUTION TO THE CULTURAL HERITAGE TOURISM
}

\author{
Pelin Şulha ${ }^{1}$
}

\begin{abstract}
In a globalizing competitive world, the communicative role of the translator in the tourism sector as a mediator between cultures and languages is essential with respect to the presentation of country's remarkable attractions and heritage. This study aims to explore in what ways the production or rewriting of the original text, based on the purpose and the function of the translational activity, enables the full appreciation of the inestimable reminiscences from the past. Turkish texts on two of the historical masterpieces in Istanbul are chosen to compare with their English versions. This analysis is carried out within the frame of Skopos theory which views translation as a cultural act to reveal behavioral patterns specific to the culture under consideration. The validity of the translator's decisions depend on not only whether the source content is transferred or not but also the strategy applied, i.e. the skopos of the action in relation to the expectations and needs of the assumed audience precedes the mode of the action and a redefinition of the relevance of certain source textual elements becomes necessary so as to attain a functional transfer (Vermeer 2004; Reiss \& Vermeer 2014). In the analysis, it is observed that the translator remains faithful to the source text which means to place the tourist audience on the periphery; for instance, he/she would find it interesting to be informed about the architectural design of the building mentioned in the Turkish text, but he/she would be even more eager to discover the real stories and secrets hidden behind the stone walls, which may be included in the translator's narration. One of the aims of translating tourism texts is to represent a country's distinctive cultural identity that offers new traditions and opportunities, so there is a leeway for the translator to move away independently from the source text and use his craft to reconstruct a target text more appealing to the tourist.
\end{abstract}

Key Words: Tourism Texts, Translation Studies, Skopos Theory, Cultural Mediator, Cultural Heritage Tourism

\section{INTRODUCTION}

In cultural tourism the moving of the cultures from one particular destination to another and how these cultures are perceived by the tourists is essential since tourism stands out as an international system of exchange (Robinson \&Smith 2006, pp.1-2). The term cultural tourism makes reference to "the cultural nature of, and the role of, tourism as a process and set of practices that revolve around the behavioral pragmatics of societies, and the learning and transmission of meanings through symbols and embodied through objects" (ibid., p.1). Tourism reflects the culture that emerges out of life itself and takes part in the change and production of cultural forms. This complicated chain of relationships reveals the problematic nature of the term cultural tourism. It is not merely used in the sense of the generation and consumption of high art and heritage, but also relates to the identity formation and self-perception of the individual and the society and thus the interpretation of the world. From a European point of view, culture is traditionally associated with the romantic, the beautiful, the educational and the moral. Hence, it would be natural to assume that these shared values found at the core of today's cultural tourism have been inspired by the grand tour of the $18^{\text {th }}$ and $19^{\text {th }}$ centuries popular among the social elite; yet

\footnotetext{
${ }^{1}$ Assistant Professor, Department of Translation and Interpreting, Faculty of Letters, Dokuz Eylul University, Tinaztepe Campus, Buca/Izmir, Turkey.
} 
there are certainly other factors, which have also promoted the steady development of the cultural heritage attractions, such as new opportunities to experience tradition and arts particularly in small cities, effective marketing campaigns focused on destination branding that conveys the notion of culture as a moral and economically beneficial product. However, to attract the cultural tourist, culture should be viewed within broader societal, political and organizational conditions of a rapidly changing world. Although cultural tourism is promising and continues to grow, the culture of the ordinary and everyday and self-indulgent activities are still at the very top of the touristic agenda; it has been observed that most tourists prefer to learn more about the daily practices and behaviors of the host culture instead of visiting the formalized cultural settings such as museums, galleries and historic buildings (ibid. pp.4-6, 8). To benefit from the economic rewards of tourism, a destination should prioritize its unique historical artifacts, which is a worthwhile venture for our country with its advantageous potential. Approaches to history in view of the different memories, emotions and concerns it evokes are likely to transform these places into new destinations of the tourist who seeks far more than enjoyment and social contact. Tourists with different backgrounds and attitudes need to build connections with their momentary environment no matter how distant it is from their own but at the same time experience the feel of otherness and appreciate nature, people and pasts unknown to them. Therefore, when visiting an attraction, the flow of information, data and messages between the sender and the receiver is important since the desired impact determines this communicational interaction (Robinson \& Smith 2006, pp. 9-10; Puczko 2006, pp. 227228, 232).

The translator as a cultural mediator should be aware of these intentional relations and make his/her choices in the translation process accordingly. In other words, as a result of the socio-economic changes and technological developments in today's globalizing world, tourists tend to discover and narrate the everyday culture where the original taste and texture meets rather spending time to gain a deeper insight into art and history. For this reason, informative texts about the cultural heritage addressed to tourists should be prepared in such a way as to capture their attention and make them believe in the idea that without full exposure to these artifacts their travel will not be able to fulfill its purpose. In this vein, the translator as a rewriter of the source texts attempts to meet the constantly changing conditions, demands and marketing strategies of the tourism sector and practicing his professional craft intervenes when necessary, i.e. the translator's perspective cannot be text-based only as the extra-linguistic factors the text is born into play an equally important role as the textual properties themselves.

\section{METHOD}

As the Greek term Skopos implies Hans Vermeer's target text oriented Skopos Theory prioritizes the intended function or purpose of a translation. Vermeer focuses on the bicultural competence of the translator since he views language as part of a culture not as an independent system. The text like the language is dynamic and shaped by the needs and expectations of the reader. In addition to the linguistic components, the representation of meanings embedded in the textual material is also related with the extra-linguistic reality expressed in various relationships. Based on this approach there is no one perfect translation and the aim and the contextual situation determines the mode in which the translation is carried out. Discussing these specifications clearly with the client who commissions the action helps the translator for his successful accomplishment of the task. 
One of the translation types the skopos theory has put forward is the communicative or instrumental translation. This type of translation gives priority to target culture norms and conventions and is produced by adaptation or modification of the source text to serve a particular purpose. Thus, the source language equivalence plays second fiddle and the practice of translation gains a more realistic identity. Moreover, the target reader is not able to distinguish at a glance between the original text and its translation. Vermeer's dynamic and holistic approach which disapproves the linguistic conception of translation seeing its practice as a cultural transfer, views purpose or function of the translation in the receiving culture as the most important factor to be considered in both the process and product of translation. It should also be noted that in most cases what the translator intends and how the translation functions in the target culture do not comply because the cultures and the audience the source and target texts address are different in various ways. Another essential function this theory emphasizes is the intratextual coherence that enables the reader to understand the given message and relate it to his/her situation. A new concept of the status of the source text brought about by the skopos theory has led to the elevation of the translator's position to an expert in translational action whose voice must be respected. As the professional responsible for the commissioned task and the final translatum, he/she is expected to predict the results of his/her choices and decisions in relation to his/her specified skopos, for instance the effect of the translated text on the receiver. The translator acts according to a commission which includes the instruction given, e.g. the specification of purpose or addressees, to carry out the translation. The target culture conditions determine whether the commission is acceptable or not. It is possible for the translator to make some adjustments concerning the purpose when necessary. These adjustments may be followed by the decisions for changes in the translatum as regards the source text. The defined skopos expands the possibilities of translation and tells the variety of strategies to be used such as paraphrasing and completely re-editing and thus translation is not limited to the faithful imitation of the source text which may result in an enforced literalness (Snell-Hornby 2006, pp.52-54; Vermeer 2004,pp.227-237).

\section{RESULTS}

In this study, Turkish texts on two of the historical masterpieces in Istanbul are chosen to compare with their English versions. The texts are taken from the website of the Istanbul Metropolitan Municipality (2008) which presents the city as the "European Capital of Culture". This analysis aims to reveal how the English translations of the websites about the kulliyes built in Uskudar and Edirnekap1 to honor Mihrimah Sultan, the only daughter of Suleyman I, may be improved within the frame of the Skopos theory to represent Turkey's distinctive socio-cultural identity and bring the cultural heritage tourism into the forefront as a means of economic welfare.

The texts displayed on the website convey brief information about the historical buildings. In the English translation some additional though limited explanations concerning the presumably unknown architectural parts are given, but they are literally true. To familiarize the tourist with the various phases of the Ottoman life becomes necessary to avoid misinterpretations. The concept of Kulliye in the Islamic tradition refers to a selfsustaining and philanthropic development established to serve the society's needs where the governmental, religious and political entities work together as one, so to leave the word as it is in the English translation may be more appropriate as the word complex used partially reveals the connotations that Kulliye includes (Jenkins 2008, p.80). Madrasa is 
described as "a theological school attached to a mosque" (Köksal 2015), however apart from the Islamic sciences; students were able to study a variety of subjects ranging from mathematics to astrology. Besides, upper level madrasa did not only provide education but also functioned as a milieu of socialization which encourage students enter into urban and cultural life (Şahin 2013, pp.21-22). An explanation related to the multidimensional notion of education in the madrasa is needed for the target reader. Both Kulliyes were built by the chief imperial architect Sinan. The Mihrimah Sultan Mosque in Edirnekap1 looks as splendid as the Selimiye Mosque. According to some myth, the nature has also adored its magnificence and once a year, owing to the designer's unique perspective into aesthetics, the sun goes down on the Edirnekap1 Mosque while the moon rises between the minarets on the Uskudar Mosque to symbolize its Sultan whose name means the sun and the moon (Sezer \& Özyalçıner 2010). Although it is not present in the source text, the translator may include this story in his target text as complementary information appealing to the tourist. To fulfill his/her task and make the necessary choices, the translator is expected to know both the features of the text type and the demands of the target audience.

\section{CONCLUSION}

Translation as an intercultural activity has a purpose or skopos which directs the translator's choices in the processing and production of translation. The translator's expertise gives him the authority and responsibility to identify this purpose that is expected to work properly for the communicative situation at hand. Tourism texts are pragmatic texts written to inform the tourist about a country's attractions and contribute to the sustainable development of the tourism sector. The mediator-translator, being aware of the changing socio-economic trends in the recent tourist demands, should be in an attempt to attract the tourist's interest to the appreciation of cultural heritage artifacts instead of the everyday activities specific to the host culture. The Skopos theory has a broader conception of the translator's task removing the traditional limitations imposed by the notion of fidelity and hence providing the opportunity to expand the use of various translation strategies for rewriting, as is the case with the translation of tourism texts.

\section{REFERENCES}

1. Akçakaya, Ali. Üsküdar Mihrimah Sultan Külliyesi. Accessed July 15 2015, http://www.ibb.gov.tr/sites/ks/tr-TR/1-Gezi-Ulasim/kulliyeler/Pages/uskudarmihrimah-sultan-kulliyesi.aspx.

2. Akçakaya, Ali. Edirnekapı Mihrimah Sultan Külliyesi. Accessed July 15 2015, http://www.ibb.gov.tr/sites/ks/tr-TR/1-Gezi-

Ulasim/kulliyeler/Pages/edirnekap\%c4\%bl-mihrimah-sultan-kulliyesi.aspx.

3. Hornby, Mary Snell (2006): The Turns of Translation Studies: New Paradigms or shifting viewpoints? Amsterdam \&Philadelphia: John Benjamins Publishing.

4. Jenkins, Eric J. (2008): To Scale: One Hundred Urban Plans. New York: Routledge.

5. Köksal, İrfan. Uskudar Mihrimah Sultan Complex. Accessed July 15 2015, http://www.ibb.gov.tr/sites/ks/en-US/1-Places-To-Go/mosques/Pages/uskudarmihrimah-sultan-complex.aspx. 
6. Köksal, İrfan. Edirnekapi Mihrimah Sultan Complex. Accessed July 15 2015, http://www.ibb.gov.tr/sites/ks/en-US/1-Places-To-

Go/mosques/Pages/edirnekap\%c4\%b1-mihrimah-sultan-complex.aspx.

7. Puczko, Laszlo (2006): "Interpretation in Cultural Tourism", in in Cultural Tourism in a Changing World: Politics, Participation and (Re) presentation. Robinson \& M., Smith M. (eds). Clevedon: Channel View Publications, pp.227243.

8. Reiss, Katharina \& Hans Vermeer (2014): Towards a General Theory of Translational Action: Skopos Theory Explained (tr. Christiane Nord). New York: Routledge.

9. Robinson, Mike \& Melanie Smith (2006): "Politics, Power and Play: The Shifting Contexts of Cultural Tourism", in Cultural Tourism in a Changing World: Politics, Participation and (Re) presentation. Robinson \&M., Smith M. (eds). Clevedon: Channel View Publications, pp. 1-17.

10. Sezer Sennur \& Adnan Özyalçıner (2010): Öyküleriyle İstanbul Anttları-I: Surlardır Kuşatan Istanbul'u. İstanbul: Evrensel Basım Yayın.

11. Şahin, Kaya (2013): Empire and Power in the Reign of Süleyman: Narrating the Sixteenth Century Ottoman World. New York: Cambridge University Press.

12. Vermeer, Hans (2004): "Skopos and Commission in Translational Action" (tr. Andrew Chesterman). Lawrence Venuti (ed.). The Translation Studies Reader, Second Edition. London\& New York: Routledge, pp.227-238. 